\title{
Catalytic conversion of Jerusalem artichoke stalk to ethylene glycol over a combined catalyst of $\mathrm{WO}_{3}$ and Raney $\mathrm{Ni}$
}

\author{
Likun Zhou a,b, Jifeng Pang a, Aiqin Wang a, Tao Zhang a,* \\ a State Key Laboratory of Catalysis, Dalian Institute of Chemical Physics, Chinese Academy of Sciences, Dalian 116023, Liaoning, China \\ b University of Chinese Academy of Sciences, Beijing 100049, China
}

\section{A R T I C L E I N F O}

\section{Article history:}

Received 4 April 2013

Accepted 5 June 2013

Published 20 November 2013

Keywords:

Lignocellulose

Jerusalem artichoke stalk

Tungsten trioxide

Raney nickel

Ethylene glycol

\section{A B S T R A C T}

Jerusalem artichoke stalk (JAS) was employed as the feedstock for the production of ethylene glycol (EG) with a combined catalyst comprising commercial $\mathrm{WO}_{3}$ and Raney Ni. The raw JAS contains 51.6 wt $\%$ cellulose, $10.3 \mathrm{wt} \%$ hemicellulose, $17.2 \mathrm{wt} \%$ lignin, $1.7 \mathrm{wt} \%$ ash, and $19.2 \mathrm{wt} \%$ water-soluble substances. It was found that the lignin component in the JAS had little effect on the conversion of hemicellulose while the water-soluble substances caused a negative effect, which led to an EG yield of only $29.9 \%$. After a simple hot water pretreatment, most of the water-soluble substances were removed, and the EG yield was increased to $37.6 \%$. Moreover, the hot water pretreatment also led to an improvement in the durability of the catalyst. The effects of reaction temperature and reaction duration were also investigated.

(C) 2013, Dalian Institute of Chemical Physics, Chinese Academy of Sciences. Published by Elsevier B.V. All rights reserved.

\section{Introduction}

Biomass is considered a promising feedstock for the sustainable production of fuels and chemicals [1-3]. Lignocellulose is the most abundant source of biomass on earth and is widely available in various agricultural wastes. The transformation of lignocellulose into value-added chemicals will not only valorize agricultural waste but can also promote $\mathrm{CO}_{2}$ recycling via plant photosynthesis [4-6]. This is particularly important given increased concerns about climate change by $\mathrm{CO}_{2}$ emission associated with the use of fossil fuels. Moreover, compared with fossil fuels such as petroleum and coal, lignocellulose has a much higher $0 / \mathrm{C}$ ratio, which offers an advantage for the production of oxygenates without the need for additional oxidation steps.

Lignocellulose is composed of lignin (15-30 wt\%), cellulose (30-60 wt\%), and hemicellulose (10-25 wt\%). Based on their chemical structures and compositions, lignin can be transformed into phenol derivatives [7-9] while cellulose and hemicellulose can be transformed into polyols [10-12]. Because the latter two components account for $70-85 \mathrm{wt} \%$ of the lignocellulose and are much easier to degrade than lignin itself, most efforts have been devoted to the transformation of (hemi)cellulose [13-15]. Among various transformations, the one-pot catalytic transformation of (hemi)cellulose into ethylene glycol (EG) is one of the promising approaches because of the high efficiency of the process [16], the high selectivity to EG [17], and the important and widespread application of EG in the plastics industry $[18,19]$. The reaction is critically dependent on the employment of multi-functional W-based catalysts. It has been reported that transition metal-promoted tungsten carbide $[16,17,20]$ or phosphide [21] and hybrid catalysts comprising tungsten oxide and a transition metal [10,22] were all active and selective for this reaction. Depending on the cata-

*Corresponding author. Tel: +86-411-84379015; Fax: +86-411-84691570; E-mail: taozhang@dicp.ac.cn This work was supported by the National Basic Research Program of China (973 Program, 2009CB226102) and the National Natural Science Foundation of China (21176235). 
lyst formulation and the reaction conditions, the yield of EG could reach $75 \%$ [17]. Although great progress has been made in the conversion of cellulose to EG, most previous studies were conducted with pure microcellulose, and this is clearly not feasible in industrial processing. Therefore, it is highly desirable to employ raw lignocellulosic materials as the feedstock for the production of EG. In our recent work, corn stalk [23] and various types of woody biomass [24] were investigated as the feedstock in the catalytic production of EG. The lignin component seriously impeded the conversion of (hemi)cellulose in the corn stalk but showed a lower effect in the case of woody biomass. When corn stalk was used as the feedstock, delignifying pretreatment, e.g. treatment with a mixture of $\mathrm{H}_{2} \mathrm{O}_{2}$ and $\mathrm{NH}_{3} \cdot \mathrm{H}_{2} \mathrm{O}$ was a prerequisite for efficient (hemi)cellulose conversion. In contrast, even without any pretreatment, a high yield of EG could be achieved when woody biomass was used as the feedstock. Hence, it appears that the conversion of raw lignocellulosic materials is dependent on the lignin content as well as the impurity minerals present.

Jerusalem artichoke is a perennial crop possessing the advantages of fast growth, drought tolerance, and easy plantability [25]. Because of the high production of Jerusalem artichoke tubers (JAT) and the high sugar content in JAT, most previous studies have focused on the transformation of JAT into value-added chemicals $[26,27]$ while the Jerusalem artichoke stalk (JAS) would be discarded. Recently, we reported the selective transformation of JAT into 1,2-propylene glycol using $\mathrm{Ni}^{-} \mathrm{WC}_{x} / \mathrm{AC}$ catalyst [28]. To accomplish the complete utilization of Jerusalem artichokes, we investigated the transformation of JAS. With a combined catalyst composed of inexpensive and commercially available $\mathrm{WO}_{3}$ and Raney $\mathrm{Ni}$, hot water-treated JAS can be transformed into EG with a yield of $37.6 \%$. To the best of our knowledge, this is the first report of JAS being converted into a value-added chemical.

\section{Experimental}

\subsection{Catalyst and treatment of JAS}

Commercial $\mathrm{WO}_{3}$ and Raney $\mathrm{Ni}$ were provided by Aladdin Chemical Co., Ltd., and Dalian Toyounger Chemical Co., Ltd., respectively. The JAS was obtained from Dalian, China. It was dried at $60{ }^{\circ} \mathrm{C}$ for $12 \mathrm{~h}$ and pulverized into particles smaller than 60 mesh. The hot water pretreatment was conducted in a round-bottom flask fitted with a reflux condenser. Typically, 10 g JAS was treated with $200 \mathrm{ml}$ of distilled water at $100{ }^{\circ} \mathrm{C}$ for 6 or $12 \mathrm{~h}$. The pretreated JAS was recovered by filtration and finally dried at $60{ }^{\circ} \mathrm{C}$ for $12 \mathrm{~h}$. The two samples are referred to JAS- 6 and JAS-12, respectively.

\subsection{Analysis and characterization}

The compositions of JAS before and after pretreatment were determined by the Van Soest method [28]. X-ray diffraction (XRD) patterns of the JAS materials were recorded on a PW3040/60 X' Pert PRO (PANalytical) powder X-ray diffractometer equipped with a $\mathrm{Cu} K \alpha$ Ni-filtered radiation source $(\lambda=$
$0.15432 \mathrm{~nm}$ ) and operated at $40 \mathrm{kV}$ and $40 \mathrm{~mA}$. Scanning electron microscopy (SEM) images of the JAS were obtained on an FEI Quanta 200 microscope operated at $20 \mathrm{kV}$, and the samples were sputter coated with a thin layer of gold before measurements were made. The contents of $\mathrm{Ni}$ and $\mathrm{W}$ leached in water after the reaction were determined using an inductively coupled plasma (ICP) spectrometer on an IRIS Intrepid II XSP instrument.

\subsection{Reaction tests}

The catalytic transformation of JAS was conducted in a stainless steel autoclave (100 ml, Parr Instrument Co.) typically with an initial $\mathrm{H}_{2}$ pressure of $6 \mathrm{MPa}$ (measured at room temperature) and at $245^{\circ} \mathrm{C}$ for $120 \mathrm{~min}$. For each reaction, JAS (0.5 g), $\mathrm{WO}_{3}$ (0.15 g), Raney Ni (0.15 g), and distilled water (50 ml) were placed in the reactor and stirred at a rate of $960 \mathrm{r} / \mathrm{min}$. After the reaction, the mixture was filtered, and the liquid phase products were analyzed with a high performance liquid chromatograph (HPLC, Agilent 1200 Series) equipped with a Shodex SC1011 packed column using water as the mobile phase and an RI detector. The yields of products were calculated using the formula: yield = (weight of product) $/$ (weight of JAS placed into the reactor) $\times 100 \%$.

\section{Results and discussion}

\subsection{Composition of JAS}

The compositions of untreated and pretreated JAS are shown in Table 1. The raw JAS contains $51.6 \mathrm{wt} \%$ cellulose, $10.3 \mathrm{wt} \%$ hemicellulose, $17.2 \mathrm{wt} \%$ lignin, $1.7 \mathrm{wt} \%$ ash, and 19.2 wt $\%$ water-soluble substances (such as proteins, minerals, and fats). After hot water pretreatment, the cellulose content decreased while both hemicellulose and lignin contents were markedly increased. Meanwhile, the water-soluble substance content dropped significantly. The composition change indicates that the hot water pretreatment removes most of water-soluble substances. As a result, the relative content of lignin was increased. The decrease in the cellulose and hemicellulose contents suggests that part of the cellulose has been transformed into hemicellulose by the hot water treatment. However, according to the Van Soest method [29], the hemicellulose and cellulose are determined by the mass that can be dissolved by dilute and concentrated $\mathrm{H}_{2} \mathrm{SO}_{4}$, respectively, rather than by their chemical structures. Therefore, the changes in the cellulose and hemicellulose contents means that only a part of the poorly crystallized or amorphous cellulose became so degradable after hot water treatment that it could be dissolved in dilute

Table 1

Composition of JAS pretreated with hot water for different times.

\begin{tabular}{lccccc}
\hline \multirow{2}{*}{$\begin{array}{l}\text { Pretreatment } \\
\text { time (h) }\end{array}$} & Cellulose & hemicellulose & Lignin & Ash & $\begin{array}{c}\text { Water-soluble } \\
\text { substances }\end{array}$ \\
\cline { 2 - 6 } & 51.6 & 10.3 & 17.2 & 1.7 & 19.2 \\
0 & 44.3 & 18.9 & 24.9 & 1.2 & 10.7 \\
6 & 42.9 & 22.8 & 25.0 & 1.2 & 8.1 \\
12 & & & & & \\
\hline
\end{tabular}




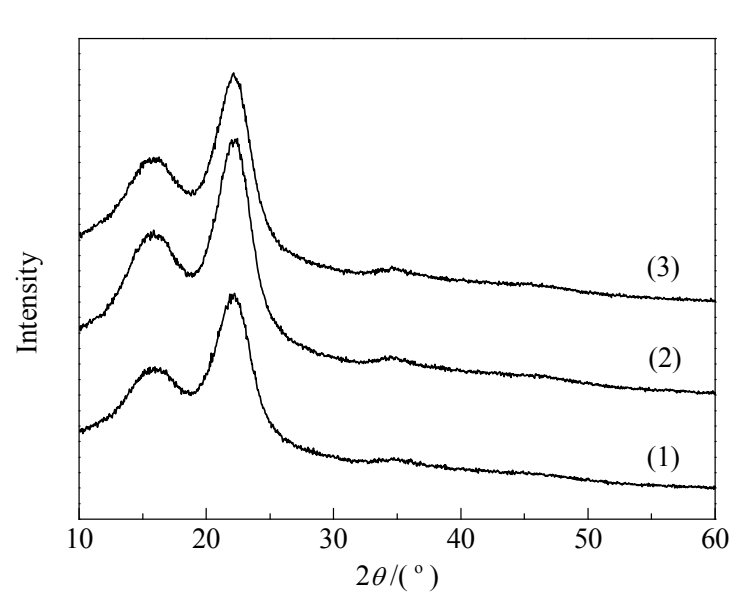

Fig. 1. XRD patterns of JAS pretreated in hot water for different times. (1) $0 \mathrm{~h}$; (2) $6 \mathrm{~h}$; (3) $12 \mathrm{~h}$.

$\mathrm{H}_{2} \mathrm{SO}_{4}$. This change will certainly be favorable to the catalytic transformation.

\subsection{Crystallinity and morphology of JAS}

Figure 1 shows the XRD patterns of the untreated and hot water treated JAS. The strong peak centered at $22.5^{\circ}$ can be ascribed to the reflection of the (002) plane of crystalline cellulose, and the weak peak centered at $18.0^{\circ}$ is due to the presence of an amorphous structure [30]. It is clear that after the hot water treatment, the peak due to crystalline cellulose became more intense. The crystallinity index (CI), which was calculated by the equation $\mathrm{CI}=\left(I_{002}-I_{\text {amorphous }}\right) / I_{002} \times 100 \%$, is often used as an indicator of cellulose crystallinity $[23,30]$. The CI values were found to be $42.4 \%, 44.7 \%$, and $44.4 \%$ for the raw JAS, the pretreated JAS-6, and the pretreated JAS-12, respectively. Clearly, there is not much difference before and after hot water treatment.

The morphological change of JAS before and after hot water pretreatment is shown in Fig. 2. The pretreated JAS appears to present smoother surfaces than does the untreated sample; this is probably because of the removal of water-soluble substances. Meanwhile, smaller cellulose fibers are exposed on the
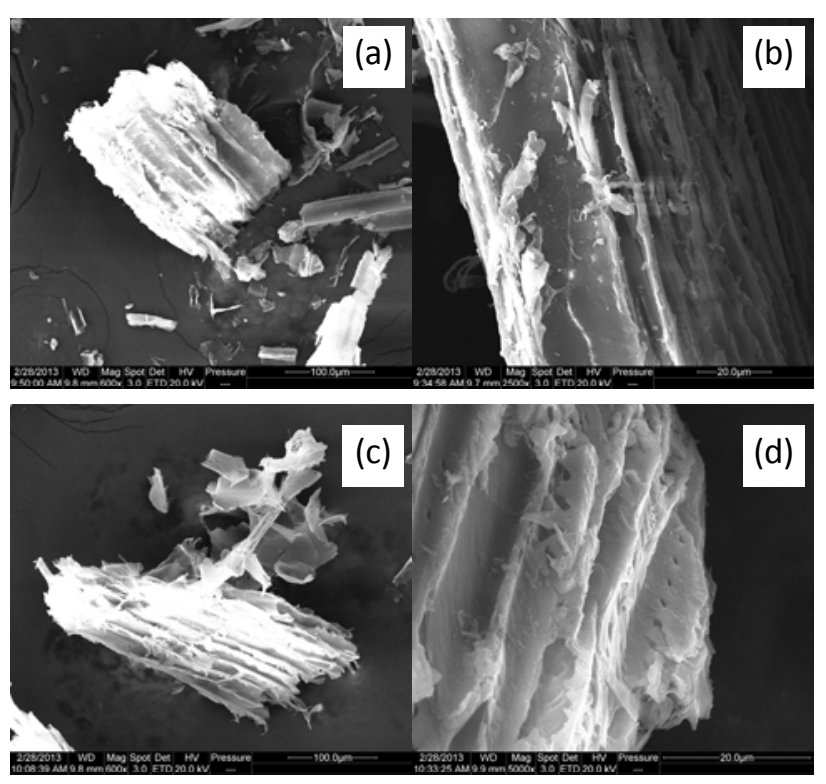

Fig. 2. SEM images of raw JAS (a, b) and pretreated JAS-12 (c, d) samples.

surfaces of pretreated JAS, and this can improve the accessibility of cellulose for its subsequent catalytic transformation [31,32].

\subsection{Catalytic transformation of JAS}

In previous work [33,34], we found that bifunctional catalysts comprising tungstic acid and Raney Ni afforded a high yield of EG and good durability for the one-pot conversion of cellulose to EG. $\mathrm{WO}_{3}$ behaves similarly to tungstic acid in this reaction, but the former is cheaper and easier to recover [34]. Therefore, $\mathrm{WO}_{3}+$ Raney Ni was used as the combined catalyst for the one-pot conversion of JAS. As shown in Table 2, for the untreated raw JAS, an EG yield of $29.9 \%$ was obtained after reaction at $245{ }^{\circ} \mathrm{C}$ for $120 \mathrm{~min}$ using $0.15 \mathrm{~g} \mathrm{WO}_{3}+0.15 \mathrm{~g}$ Raney $\mathrm{Ni}$ as the catalyst (entry 1 ). The EG yield was increased to $35.2 \%$ and $37.6 \%$ when JAS was pretreated (entries 2 and 3 ). Because the total contents of cellulose and hemicellulose are not significantly changed on pretreatment (Table 1), the en-

Table 2

Catalytic transformation of JAS pretreated under different conditions.

\begin{tabular}{|c|c|c|c|c|c|c|c|c|c|c|c|}
\hline \multirow{2}{*}{ Entry } & \multirow{2}{*}{ Pretreatment time (h) } & \multicolumn{2}{|c|}{ Catalyst amount (g) } & \multicolumn{8}{|c|}{ Yield (\%) } \\
\hline & & $\mathrm{WO}_{3}$ & Raney Ni & EG & 1,2-PG & Gly & Acetol & Ery & 1,2-BD & Sor & Man \\
\hline 1 & 0 & 0.15 & 0.15 & 29.9 & 5.4 & 2.6 & 1.4 & 2.0 & 2.0 & 1.0 & 1.0 \\
\hline 2 & 6 & 0.15 & 0.15 & 35.2 & 5.9 & 4.6 & 4.9 & 2.7 & 4.3 & 0.6 & 2.1 \\
\hline 3 & 12 & 0.15 & 0.15 & 37.6 & 6.3 & 4.9 & 4.6 & 2.8 & 4.7 & 0.7 & 2.4 \\
\hline 4 & 12 & 0.05 & 0.15 & 33.2 & 5.5 & 4.4 & 4.9 & 2.2 & 4.5 & 0.5 & 2.0 \\
\hline 5 & 12 & 0.15 & 0.05 & 36.2 & 6.8 & 2.3 & 1.3 & 0.9 & 3.3 & 0.5 & 0.9 \\
\hline 6 & 12 & 0.05 & 0.05 & 34.5 & 7.0 & 2.8 & 1.7 & 1.0 & 3.3 & 0.3 & 1.0 \\
\hline $7^{a}$ & 12 & 0.15 & 0.15 & 37.7 & 4.7 & 4.3 & 3.3 & 2.3 & 3.4 & 0.3 & 1.1 \\
\hline $8^{b}$ & 12 & 0.15 & 0.15 & 15.2 & 2.5 & 6.9 & 3.0 & 1.8 & 1.9 & 0.8 & 2.1 \\
\hline $9^{c}$ & 12 & 0.15 & 0.15 & 32.7 & 7.6 & 4.0 & 4.5 & 2.1 & 4.1 & 0.7 & 1.7 \\
\hline
\end{tabular}

Reaction conditions: JAS $0.5 \mathrm{~g}$, distilled water $50 \mathrm{ml}, \mathrm{H}_{2} 6 \mathrm{MPa}, 245^{\circ} \mathrm{C}, 120 \mathrm{~min}$.

a The JAS pretreated with $15 \%$ ammonia at $60^{\circ} \mathrm{C}$ for $12 \mathrm{~h}$ with the weight ratio of raw JAS/ammonia $=1: 10$.

b $0.01 \mathrm{mmol} \mathrm{CaCl}_{2}$ was introduced.

c $0.01 \mathrm{mmol} \mathrm{MgSO}_{4}$ was introduced.

EG: ethylene glycol; 1,2-PG: 1,2-propylene glycol; Gly: glycerol; Ery: erythritol; 1,2-BD: 1,2-butanediol; Sor: sorbitol; Man: mannitol. 
hancement in the EG yield is ascribed to the increase in (hemi)cellulose conversion. The EG yield, based on the content of (hemi)cellulose in the feedstock, was $56.3 \%$ and $48.3 \%$ for the pretreated JAS-12 and untreated JAS, respectively. This behavior was reflected in the total polyols yield. For the untreated JAS, the total polyols yield was only $45.3 \%$ while it was $64.0 \%$ for the pretreated JAS-12 feedstock. Clearly, hot water pretreatment under milder conditions could greatly enhance the conversion of (hemi)cellulose. Moreover, it was found that a change in the relative amounts of $\mathrm{WO}_{3}$ and Raney $\mathrm{Ni}$ only slightly affected the yield of EG (entries 4-6) possibly because of the higher amount of catalyst used. Even when the catalyst amount was reduced by $2 / 3$, i.e., $0.05 \mathrm{~g} \mathrm{WO}_{3}+0.05 \mathrm{~g}$ Raney $\mathrm{Ni}$, the EG yield was still $34.5 \%$. According to our previous work [34], $0.05 \mathrm{~g} \mathrm{H}_{2} \mathrm{WO}_{4}+0.05 \mathrm{~g}$ Raney $\mathrm{Ni}$ was the best quantity of catalyst for treating $0.5 \mathrm{~g}$ cellulose. Nevertheless, an excess amount of catalyst will be necessary for treating raw lignocellulose feedstock (pretreated or untreated) considering that lignin, ash (silicates), and mineral impurities in the raw materials may accumulate on the catalyst surface and cover a part of the active sites. This is particularly important for the reusability of the catalyst.

It was found that the lignin component seemed to exert little impact on the conversion of (hemi)cellulose. Although the pretreated JAS has a higher lignin content than does the raw JAS, the (hemi)cellulose could be converted more efficiently in the case of the former. This is quite different from the conversion of corn stalk, in which lignin must be removed by ammonia pretreatment, otherwise the conversion of (hemi)cellulose is significantly inhibited [23]. For comparison, we treated JAS with ammonia according to the reported procedure [23] and found that the ammonia-treated JAS afforded an EG yield (entry 7) similar to that obtained with a hot water-treated sample. This control experiment further confirmed that the lignin component in JAS had a less marked effect on (hemi)cellulose transformation compared with that of corn stalk. In contrast, the water-soluble substances appear to have negative impact on the (hemi)cellulose conversion. After removal of most of the water-soluble substances, the (hemi)cellulose conversion was higher. To further identify what impurity in the water-soluble substances poisoned the catalyst, we purposely introduced $\mathrm{Ca}^{2+}$ or $\mathrm{SO}_{4}{ }^{2-}$ in the reaction system. The result showed that 0.01 mmol $\mathrm{Ca}^{2+}$ in the reaction system led to a significant drop in the catalytic activity, and the EG yield decreased from $37.6 \%$ to $15.2 \%$ (entry 8). In contrast, the introduction of $0.01 \mathrm{mmol}$ $\mathrm{SO}_{4}{ }^{2-}$ caused only a slight decrease in the EG yield (entry 9). Clearly, $\mathrm{Ca}^{2+}$ in the raw JAS is a fatal poison for the conversion of (hemi)cellulose.

Subsequently, we investigated the effect of reaction temperature and reaction duration on the transformation of pretreated JAS-12. As shown in Fig. 3(a), the EG yield markedly increased with an increase in reaction temperature and reached $41.4 \%$ at $255^{\circ} \mathrm{C}$. In contrast, the yields of other polyols did not change much with the reaction temperature, and all of them were below 5\%. Similar to the effect of higher reaction temperature, a longer reaction duration also favored higher EG yields, but the effect was less marked (Fig. 3(b)). Compared
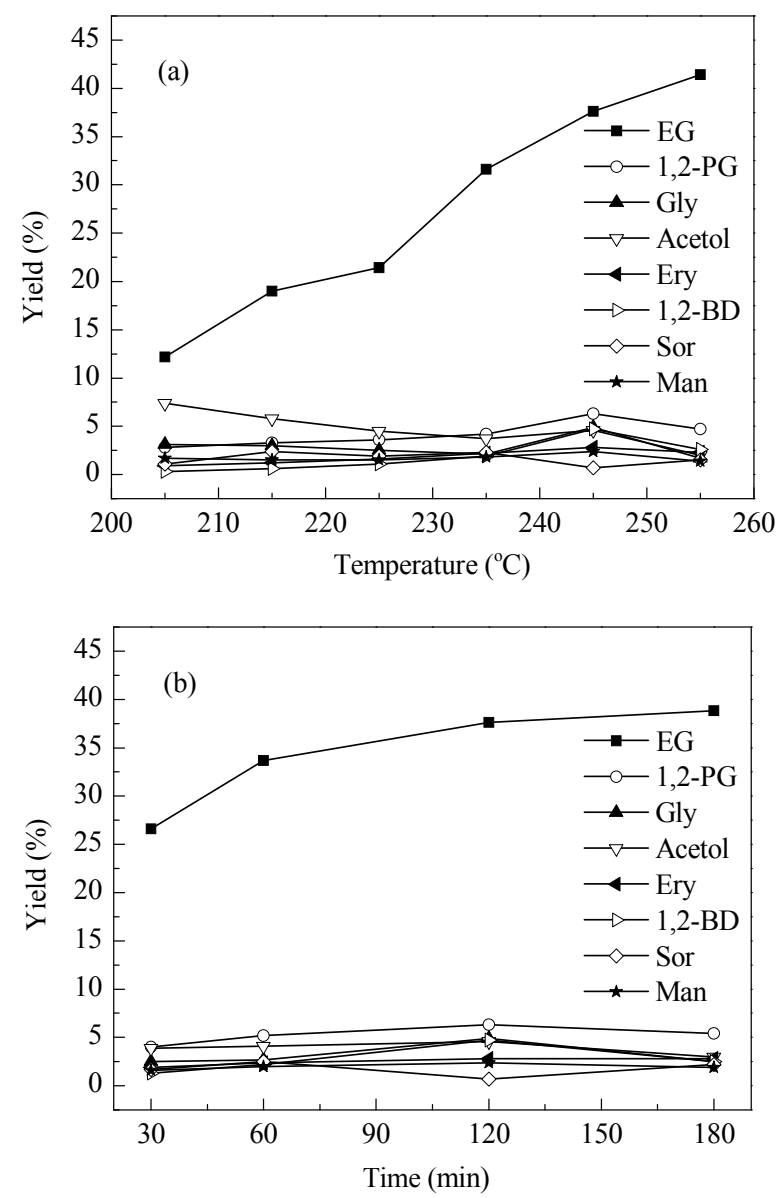

Fig. 3. The influence of reaction temperature (a) and time (b) on the transformation of pretreated JAS-12. Reaction conditions: JAS $0.5 \mathrm{~g}$, distilled water $50 \mathrm{ml}, 0.15 \mathrm{~g} \mathrm{WO}_{3}+0.15 \mathrm{~g}$ Raney Ni, $\mathrm{H}_{2} 6 \mathrm{MPa}, 120 \mathrm{~min}$ for (a), $245^{\circ} \mathrm{C}$ for (b).

with the conversion of pure cellulose [17], it is clear that the JAS conversion needs a higher reaction temperature and a longer reaction duration to obtain a comparable EG yield, demonstrating the impeding effect of lignin, ash, and other impurities [8,23].

Finally, we evaluated the reusability of the combined catalyst in the conversion of untreated and hot water-treated JAS-12. As shown in Fig. 4(a), the catalyst was deactivated after three repetitive runs with untreated JAS. The EG yield dropped from $29.9 \%$ in the first run to $9.4 \%$ in the third run, and the total polyols yield decreased from $45.3 \%$ to $24.0 \%$. In contrast, for the hot water-treated JAS-12, the EG yield remained almost unchanged after the three runs although the total polyols yield decreased slightly (Fig. 4(b)). Evidently, hot water pretreatment can reduce the deactivation of the catalyst and therefore extend the catalyst life. By careful examination of the product distribution it is seen that the acetol yield was higher in the third run with untreated raw JAS (Fig. 4(a)), which implies that the hydrogenation capability of the Raney Ni was lower. The XRD examination (Fig. 5) of the catalyst after reaction with untreated JAS clearly showed the appearance of a new phase, $\mathrm{CaWO}_{4}$, which resulted from the reaction between $\mathrm{Ca}^{2+}$ in the JAS and the $\mathrm{WO}_{3}$ catalyst. The $\mathrm{CaWO}_{4}$ formed will partially cov- 


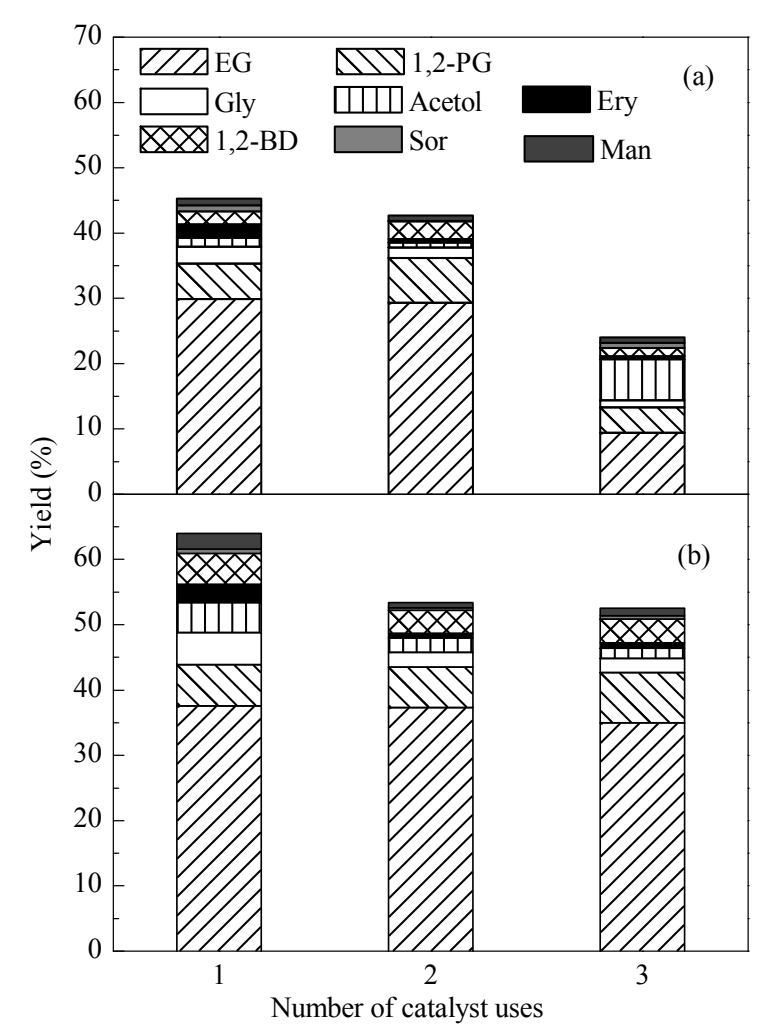

Fig. 4. Reusability of catalyst in the conversion of untreated (a) and hot water-treated (b) JAS.

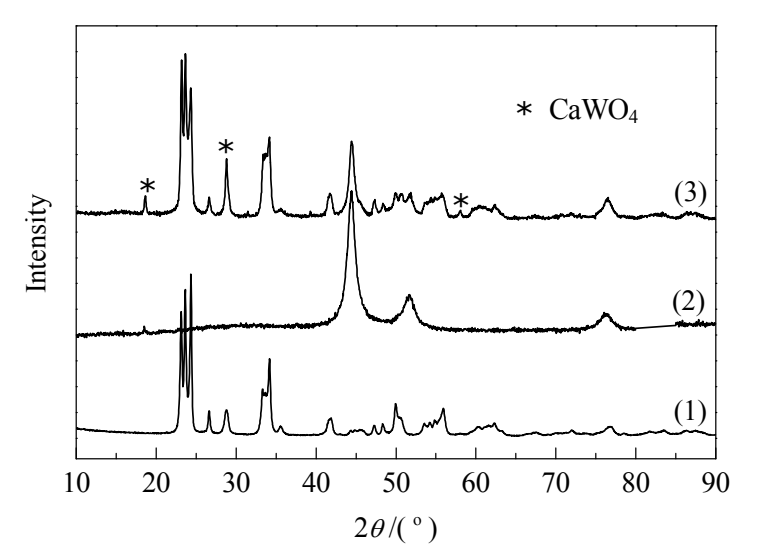

Fig. 5. XRD patterns of fresh $\mathrm{WO}_{3}(1)$, Raney $\mathrm{Ni}$ (2), and used catalyst (3) (JAS as feedstock).

er the active $\mathrm{WO}_{3}$ surface, leading to catalyst deactivation. After hot water pretreatment, most mineral impurities including $\mathrm{Ca}^{2+}$ were removed, and the catalyst reusability was improved. Although the XRD pattern of Raney Ni was not significantly changed by the reaction, the leaching of $\mathrm{Ni}$ was not negligible. The ICP analysis of the liquid phase after the reaction indicated $74.4 \mathrm{ppm} \mathrm{Ni}$ and $4.2 \mathrm{ppm}$ Al leaching from the Raney $\mathrm{Ni}$. The loss of Ni could be responsible for the decrease in the hydrogenation activity of the Raney $\mathrm{Ni}$.

\section{Conclusions}

An efficient method has been provided for transforming the agricultural waste JAS to EG with a high selectivity over a combined catalyst comprising $\mathrm{WO}_{3}$ and Raney Ni. Although the lignin component in the JAS exerted only a slight effect on the conversion of (hemi)cellulose, some water-soluble impurities, especially $\mathrm{Ca}^{2+}$, affected it negatively. After hot water pretreatment, most of the water-soluble impurities were removed, and the EG yield was greatly enhanced.

\section{References}

[1] Huber G W, Chheda J N, Barrett C J, Dumesic J A. Science, 2005, 308: 1446

[2] Goldemberg J. Energy Environ Sci, 2008, 1: 523

[3] Ma J P, Yu W Q Wang M, Jia X Q, Lu F, Xu J. Chin J Catal (马继平, 于 维强, 王敏, 贾秀全, 路芳, 徐杰. 催化学报), 2013, 34: 492

[4] Mascal M, Nikitin E B. Green Chem, 2010, 12: 370

[5] Zhou C H, Xia X, Lin C X, Tong D S, Beltramini J. Chem Soc Rev, 2011, 40: 5588

[6] Long J X, Li X H, Guo B, Wang F R, Yu Y H, Wang L F. Green Chem, 2012, 14: 1935

[7] Zhao C, Kou Y, Lemonidou A A, Li X B, Lercher J A. Angew Chem Int Ed, 2009, 48: 3987

[8] Song Q, Wang F, Xu J. Chem Commun, 2012, 48: 7019

[9] Song Q, Wang F, Cai J Y, Wang Y H, Zhang J J, Yu W Q Xu J. Energy Environ Sci, 2013, 6: 994

[10] Wang A Q, Zhang T. Acc Chem Res, 2013, 46: 1377

[11] Fukuoka A, Dhepe P L. Angew Chem Int Ed, 2006, 45: 5161

[12] Luo C, Wang S, Liu H C. Angew Chem Int Ed, 2007, 46: 7636

[13] Pang J F, Wang A Q, Zheng M Y, Zhang T. Chem Commun, 2010, 46: 6935

[14] Zhang Y H, Wang A Q Zhang T. Chem Commun, 2010, 46: 862

[15] Li C Z, Zhao Z K. Adv Synth Catal, 2007, 349: 1847

[16] Ji N, Zhang T, Zheng M Y, Wang A Q, Wang H, Wang X D, Chen J G. Angew Chem Int Ed, 2008, 47: 8510

[17] Zheng M Y, Wang A Q Ji N, Pang J F, Wang X D, Zhang T. ChemSusChem, 2010, 3: 63

[18] Yue H R, Zhao Y J, Ma X B, Gong J L. Chem Soc Rev, 2012, 41: 4218

[19] Ma J P, Pang Y, Wang M, Xu J, Ma H, Nie X. J Mater Chem, 2012, 22: 3457

[20] Ji N, Zhang T, Zheng M Y, Wang A Q Wang H, Wang X D, Shu Y Y, Stottlemyer A L, Chen J G. Catal Today, 2009, 147: 77

[21] Zhao G H, Zheng M Y, Wang A Q, Zhang T. Chin J Catal (赵冠鸿, 郑 明远, 王爱琴, 张涛. 催化学报), 2010, 31: 928

[22] Liu Y, Luo C, Liu H C. Angew Chem Int Ed, 2012, 51: 3249

[23] Pang J F, Zheng M Y, Wang A Q Zhang T. Ind Eng Chem Res, 2011, 50: 6601

[24] Li C Z, Zheng M Y, Wang A Q, Zhang T. Energy Environ Sci, 2012, 5: 6383

[25] Kays S J, Nottingham S F. Biology and Chemistry of Jerusalem Artichoke: Helianthus Tuberosus L. Boca Raton: CRC Press, 2007

[26] Ge X Y, Zhang W G. Food Technol Biotechnol, 2005, 43: 241

[27] Cheng Y, Zhou W G, Gao C F, Lan K, Gao Y, Wu Q Y.J Chem Technol Biotechnol, 2009, 84: 777

[28] Zhou L K, Wang A Q Li C Z, Zheng M Y, Zhang T. ChemSusChem, 2012, 5: 932

[29] Goering H K, Van Soest P J. Forage Fiber Analysis, USDA-ARS Agriculture Handbook Number 379. Washington DC: Agricultural Research Service, United States Department of Agriculture, 1970. 12

[30] Dhepe P L, Fukuoka A. ChemSusChem, 2008, 1: 969

[31] Nitsos C K, Matis K A, Triantafyllidis K S. ChemSusChem, 2013, 6: 


\title{
Graphical Abstract
}

Chin. J. Catal., 2013, 34: 2041-2046 doi: 10.1016/S1872-2067(12)60686-X

Catalytic conversion of Jerusalem artichoke stalk to ethylene glycol over a combined catalyst of $\mathrm{WO}_{3}$ and $\mathrm{Raney} \mathrm{Ni}$

Likun Zhou, Jifeng Pang, Aiqin Wang, Tao Zhang*

Dalian Institute of Chemical Physics, Chinese Academy of Sciences; University of Chinese Academy of Sciences

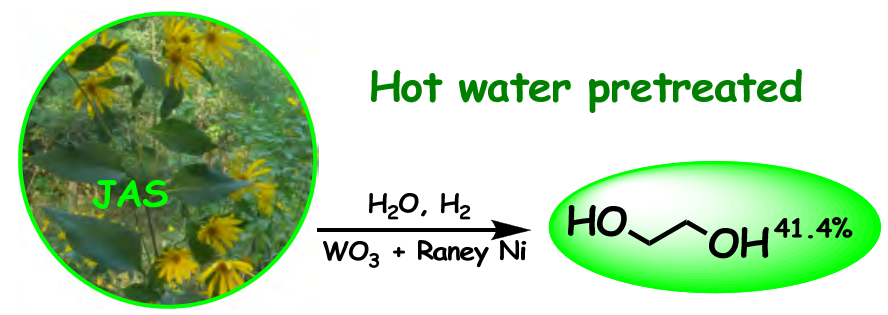

Over the combined catalyst of $\mathrm{WO}_{3}$ and Raney $\mathrm{Ni}$ hot water-treated Jerusalem artichoke stalk (JAS) was selectively converted into ethylene glycol with a yield of $41.4 \%$.

\section{0}

[32] De Frias J A, Feng H. Green Chem, 2013, 15: 1067

[33] Tai Z J, Zhang J Y, Wang A Q, Zheng M Y, Zhang T. Chem Commun,
2012, 48: 7052

[34] Tai Z J, Zhang J Y, Wang A Q, Pang J F, Zheng M Y, Zhang T. ChemSusChem, 2013, 6: 652

\section{组合催化剂 $\mathrm{WO}_{3}+\mathrm{Raney} \mathrm{Ni}$ 上高效转化菊芋秸秆制乙二醇}

\author{
周立坤 ${ }^{\mathrm{a}, \mathrm{b}}$, 庞纪峰 ${ }^{\mathrm{a}}$, 王爱琴 ${ }^{\mathrm{a}}$, 张 涛, \\ ${ }^{\mathrm{a}}$ 中国科学院大连化学物理研究所催化基础国家重点实验室, 辽宁大连 116023 \\ ${ }^{\mathrm{b}}$ 中国科学院大学, 北京 100049
}

摘要: 采用商业 $\mathrm{WO}_{3}$ 和Raney $\mathrm{Ni}$ 为组合催化剂, 以菊芋秸秆为反应原料制备了乙二醇. 菊芋秸秆中含纤维素 $51.6 \mathrm{wt} \%$ 、半纤维素 $10.3 \mathrm{wt} \%$ 、木质素 $17.2 \mathrm{wt} \%$ 、灰分 $1.7 \mathrm{wt} \%$ 和水溶性物质 $19.2 \mathrm{wt} \%$. 木质素对纤维素和半纤维素的转化影响较小, 而水溶性物质的 存在抑制了乙二醇的生成, 因此由未经过预处理的菊芋秥秆得到的乙二醇收率只有 $29.9 \%$. 而经简单的热水预处理可除掉其中的 大部分水溶物, 因而乙二醇收率提高到 $37.6 \%$. 此外, 组合催化剂在经过热水预处理的菊芋秸秆的转化中表现出了更好的循环使 用性能. 同时考察了反应温度和时间对菊芋秸秆转化的影响.

关键词: 木质纤维素; 菊芋秸秆; 三氧化铇; 雷尼镍; 乙二醇

收稿日期: 2013-04-04. 接受日期: 2013-06-05. 出版日期: 2013-11-20.

*通讯联系人. 电话: (0411)84379015; 传真: (0411)84691570; 电子信箱: taozhang@dicp.ac.cn

基金来源: 国家重点基础研究发展计划(973计划, 2009CB226102); 国家自然科学基金(21176235).

本文的英文电子版由Elsevier出版社在ScienceDirect上出版(http://www.sciencedirect.com/science/journal/18722067). 